\title{
Marine Biological Research in Mozambique: Past. Present and Future
}

This synopsis describes the development of marine biological research, including fisheries, in Mozambique. With around $3000 \mathrm{~km}$ of coastline, the living resources of the sea playa major role in the Mozambican society, mainly as a source of protein and income for the population, and of foreign revenue through exports.

In the first years, after independence, in 1975, research activities in marine sciences were limited and mainly concentrated to fisheries through cooperation with Norway and the Soviet Union. A new era for biology started in 1985 when the Faculty of Biology at Universidade Eduardo Mondlane was reopened. A $5 y r$ curriculum towards a licentiate degree was introduced with a strong marine profile. Since the 1990 s, a very dynamic development in Mozambican marine biological research has occurred. Several academic degrees in marine biology from universities abroad were obtained, and local expertise developed; building vital institutions and enrolling in advanced research activities,

In later years, the European Union and Portugal joined the mainly Scandinavian supported scheme, in giving substantial academic and financial support to marine biological education and research in Mozambique, and in other countries in the Western Indian Ocean (WIO) region, Different consortia of European institutions were involved in each program, but consistently the Department of Biological Sciences of University Eduardo Mondlane, including the Marine Biological Station at Inhaca Island, were involved. The long-term programs, such as the cooperative scheme of Sweden, allow aims for a number of objectives, e.g. support of $\mathrm{PhD}$ programs, which are not possible in simple short-term research projects. European Union projects fund specific research targets, on a 3-yr basis, have obvious limitations for long-term activities. They constitute however an excellent complement to the regular cooperative schemes.

Regional collaboration such as Marine Science for Management, (MASMA) has also been strengthened by these projects, as common goals are set, methods are standardized and appropriate regional comparisons are possible. These have increased collaboration between Mozambican researchers, and their regional and European counterparts, diversifying the acquisition of new research areas, and different approaches to scientific activities.

Higher education in Mozambique, marine research in particular, are still heavily dependent on support from outside, but there is now a solid Mozambican academic platform for marine biological research. The production of some 300 papers and reports, of which over 50 have been published in international peer-reviewed journals, speak for themselves.

\section{THE ROLE OF INHACA MARINE BIOLOGICAL STATION}

The development of marine biological research in Mozambique, and particularly at the University Eduardo Mondlane, is closely linked to the existence of the Inhaca Marine Biological Station (EBMI). The station, founded in 1951 at Inhaca Island, $30 \mathrm{~km}$ off Maputo in southern Mozambique, has been a cornerstone in the development of biological science in Mozambique. Despite the small size of the island (approx. $40 \mathrm{~km}^{2}$ ), it has a wide variety of coastal ecosystems including mangroves, tidal flats, seagrass meadows, rocky and sandy shores and coral reefs, making it ideal for fieldwork in both terrestrial and marine biology. It lies in the region of transition from tropical to subtropical climate and it constitutes a barrier between the shallow Maputo Bay and the open Indian Ocean.

During the initial years, research was mainly carried out by scientists from South Africa and by Portuguese staff. Major achievements were made and the classical work The Natural History of Inhaca Island by Macnae and Kalk in 1958 and 1969 (1), revised by Kalk 1995 (2), is still a basic textbook for all scientists visiting the island. The re-opening of the Faculty of Biology at University E. Mondlane in 1985, was also the starting point for a new era in the history of the Station. Through major financial and technical support from mainly Sweden and Norway, a restoration of the infrastructure of the Station and the protection of the reserves could be initiated.

Students on field courses and scientists from near and far began to use the facilities. The Station gradually became important at the national, regional, and international level. Most students used Inhaca as a base for their research work and several university staff developed their research at Inhaca, attracting scientists from abroad as counterparts for research projects.

In the last 20 years, close to 100 undergraduates, $10 \mathrm{MSc}$ and $5 \mathrm{PhD}$ degrees were achieved based on research carried out at Inhaca. More than $70 \%$ of the country's marine biological research papers were developed at Inhaca.

\section{BIOLOGICAL AND ECOLOGICAL RESEARCH}

Development of research capacity has expanded the fields of interest and scientific approaches. Areas of research have been created having a taxonomic basis, others at population and ecosystem function levels. Studies on pelagic and offshore organisms were mostly restricted to those related to fisheries. Marine biological research has targeted on mainly coastal systems, such as mangroves, seagrass meadows, tidal flats, coral reefs and shallow waters, with facilitated access through conventional low cost means. A summary of research output in marine biology is shown in Figure I. A full list of papers and reports is available at hup:// www.uem.mz

\section{Mangroves}

Mangroves in Mozambique cover an area of approximately 396000 ha and occur mostly in sheltered shorelines and river estuaries, along almost the entire coastal area (3). The riverine mangroves of the Zambezi river and Quelimane are the largest in Mozambique extending $50 \mathrm{~km}$ inland, and covering up to $180 \mathrm{~km}$ of coastline (4). The Zambezi delta contains one of the single-largest areas of mangrove forests in Africa and represents close to $50 \%$ of mangroves in Mozambique. Nine mangrove tree species occur in Mozambique.

Mangrove research has covered biological, physical, and socioeconomical aspects, emphasizing taxonomy, mangrove distribution, fauna and flora associations and biophysical requirements, mangrove demographic profiles and mangrove products such as firewood and building material (4-6).

\section{Seagrasses}

There are 13 seagrass species in Mozambique which may cover up to $80 \%$ of the intertidal areas. The first publications on seagrasses were those by Moss (7) and Cohen (8); followed by studies dealing mostly with the seagrasses of Inhaca (9). More specific works reported on ecophysiology, distribution, structure, nutrients, and molecular biology (10-14). Studies on interactions of different seagrass associations with associated fish and

\section{(C) Royal Academy of Sciences 2002 http://www.ambio.kva.se}


infaunal communities were also conducted (e.g. 15). One third of around 60 references published in this region, refer to the seagrasses of Mozambique (16).

\section{Algal Research}

Microalgal research has mainly been carried out in southern Mozambique and dealt mainly with the blue-green algae of Inhaca (17). Other studies covered chlorophyll fluctuations (18). Basic microalgal research is still needed in Mozambique. Most seaweed research was conducted in southern Mozambique, focusing on aspects of taxonomy and biogeography (1921) and also in northern Mozambique have been subject to more detailed studies covering seaweed assemblages (22). Po- based on industrial catches and regular tential economic seaweeds, some of them scientific cruises.

with ethnobotanical value were documented (e.g. 23, 24). Eucheuma and Kappaphycus strains from The Philippines have been farmed in northern Mozambique for export.

\section{Coral Reefs}

Around 140 species of coral reefs were identified at Inhaca (1). The numbers for the entire country are unknown. Corals occur mostly in northern Mozambique, in coral limestone fringing reefs, but also in southern Mozambique at Bazaruto and Inhaca. Around 40 works have been produced covering aspects such as fisheries at coral reefs, management and monitoring, coral systematics, coral bleaching and trade of ornamental coral fish (25).

\section{Crustacean Research}

Most research studies on decapod crustaceans, with the exception of the commercial species, were carried out at Inhaca, Maputo Bay, and Quirimbas. The results ranged from taxonomic descriptions of newly hatched brachyuran crabs to descriptions of new shrimp species (e.g. $26,27)$. Information on zoogeography of southern African decapods (including Mozambique) and studies on littoral shrimp composition as evidence of climate conditions have also been undertaken (e.g. 28). Commercial shrimp species have been subject to more detailed studies based on industrial catches and regular scientific cruises (29).

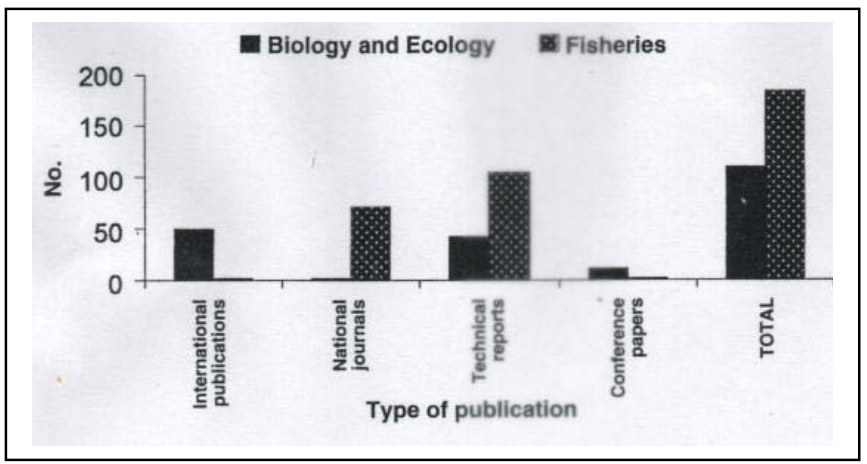

done south of the 18th parallel.

\section{Fisheries Research}

The first published accounts on fisheries studies from Mozambique date from 1966 $(41,42)$, at the start of industrial fisheries for marine shrimps, but before the creation of the fisheries research body. At the time of national independence, only a preliminary assessment of shrimps in the main fishing areas, Maputo Bay and Sofala Bank, had been published (43) as well as on small-scale clam, crab and kellee shad fisheries $(44,45)$.

The first major work in fisheries research after national independence was a series of surveys by Soviet trawlers (Profs Mesyatsev and Aelita) and by the Norwegian $\mathrm{R} / \mathrm{V}$ Dr. Fridtjof Nansen, covering the coastal area as well as offshore resources (46). These surveys paved the way for the development of several industrial fisheries such as the scad and Indian mackerel trawl fishery in the Sofala bank, and the deep-water crustacean fisheries. The Fisheries Research Institute was founded in 1977 and, in 1980, the Revista de Investigacao Pesqueira (Fisheries Research Journal) was created.

The surveys that followed this first phase, have been centered on specific resources, fishing gear or area, such as the study of tuna resources of the Mozambican EEZ accessible to deep-water long line; deep-water shrimp resources (47); scad and Indian mackerel (48); shrimp biomass in Sofala bank $(49,50)$. Until December 2000, more than 60 surveys had been performed, some of them with multiple ships.

Research on small pelagic fish (51); deep-water spiny lobster (Palinurus delagoae) and deep-water crab (Chaeceon quinquedens) were also studied $(35,47)$. The relationship between the shrimp fishery and the environment was also investigated $(52,53)$.

For recommendations on sustainable resource use, research on biological yield was performed $(29,54-57)$. Research on artisanal fisheries has also been conducted. Here difficulties include lack of access to most fishing centers. Complementary reports to the above include demersal trawlable resources, line-fishable offshore resources (51).

\section{LEGISLATION AND CONSERVATION OF MARINE RESOURCES}

Bazaruto National Park, Inhaca, Marromeu, Pomene Reserves, Maputo Special Reserve and the newly created Quirimbas National Park are the only areas in Mozambique where marine resources are under conservation. Primeiras and Segundas islands in central Mozambique have also 
been suggested for conservation. Threatened species in Mozambique include dugongs, coastal dolphins (Sousa chinensis and Tursiops truncatus), whale shark, all sea turtle species, sea-cucumbers (Holothuria scabra, H. atra), molluscs (Tridacna maxima) and coral reefs. The sea grasses Halophila ova/is subsp. /iniaris (endemic to Maputo Bay) and Zostera capensis are threatened. The mangrove Pemphis addula, occurs in small quantities in northern Mozambique and is also threatened.

In terms of National legislation, Mozambique has passed the following laws.

Framework of Environmental Law, 1997, provides the basis for the creation of both marine and terrestrial protected areas and conservation and rehabilitation of degraded habitats.

- The Land Law, 1997, promotes the creation of totally and partially protected areas, conservation and management of coastal habitats. The territorial sea, the exclusive economic zone, the strip of maritime coast and along the coast of islands, bays and estuaries (from the maximum high tidal level to a mark of 100 metres inland) are considered zones of partial protection.

The New Forestry and Wildlife Law, 1999, has a key principle that local communities must be fully involved in

the conservation and sustainable use of resources including marine. This law recognizes three types of protected zones: national parks, national reserves and historicalcultural zones.

- The Fisheries Law, 1990, states that all fisheries resources belong to the state (public domain) and that the state decides on proper resources management. The use of explosives or toxic substances and electrocution for fishing is prohibited. This law includes also protected species such as dugongs, dolphins and turtles. Mozambique has also ratified: the Convention on Biological Biodiversity; the United Nations Law for the Sea; and the CITES convention. Mozambique is affiliated to the African Convention for Nature Conservation and is in the process of affiliation to the RAMSAR convention (Wetlands Convention) which also covers shallow marine waters.

\section{PERSPECTIVES IN MARINE BIOLOGICAL RESEARCH IN MOZAMBIQUE}

As local capacities, both in terms of human and infrastructural resources develop, the interaction of biology with other fields of marine research will widen the scope of most activities and increase collaboration. which will be more appropriately treated within the marine sciences. Obvious interacting areas of research are physics (oceanography/hydrology), marine chemistry (nutrients, pollution), marine geology (sedimentology), climatology (drainage basins) and socioeconomics. This process should be related to the development of appropriate advanced curricula of post-graduate education. In this context, the scope and structure of the Station at Inhaca should become much broader to support all marine related sciences.

Fisheries bodies will continue with environmental and resource-fisheries monitoring, but will also proceed with specific studies aiming to develop elaborate stock assessment models. A new molecular biology lab has been installed at Fisheries Research Institute, enabling it to start a new line of work and to provide services to potential research and management customers. Research in aquaculture has recently been resumed and will continue to be a source of advice and support to the growing aquaculture industry.

\section{$\underline{\text { References and Notes }}$}

I. Macnae, W. and Kalk, M. 1969. A Natural History of Inhaea Islalld. Mozambique. Witwatersrand Univ. Press, Johannesburg. $163 \mathrm{pp}$.

2. Kalk, M. 1995. A Natural History of Inhaca Island Mozambique. Witwatersrand Univ. Press, Johannesburg. $395 \mathrm{pp}$.

3. Saket, M. and Matusse, R. 1994. Study for the determination of the rate of deforestation of the mangrove vegetation in Mozambique. DNFFB. FAO/PNUDI MOZ/92/013. 9 pp

4. Barbosa, F.M.A., Cuambe. e.C. and Bandeira, S.O. 2001 Status and Distribution of mangroves in Mozambique S. AIr. J Bot. 67,393-398.

5. Hatton, J.e. and Couto, A.L 1992. The effect of coastline changes on mangrove community structure, Portugues Island, Mozambique. lIydrohiologia 247, 4957.

6. Guerreiro, J., Freitas, S., Pereira, P., Paula, 1. and Macia, A. 1996. Sediment macrobenthos communities of mangrove flats at Inhaca island, Mozambique. Cah Bioi. Mar. 37, 309-321.

7. Moss, M. 1937. A preliminary account of the 'seagrasses' of Delagoa bay. S. Afr. J Sci. 33,234-345. 8. Cohen, E. 1939. The marine angiosperms oflnhaca Is land. S. Afr. .J. Sci. 36, 246-256.

9. Macnae, W. 1969. Sea grasses. In: A Natural History of Illhaea Islalld, Mozambique. Macnae, W. and Kalk, M. (eds), Witwatersrand Univ. Press, Johannesburg, pp. 2830.

10. Johnson, J.M., Choinski Jr. J.S., Heyes, J,A. and Bandeira, S.O. 1993. Factors affecting photosynthesis in the Mozambican seagrasses Cymodoeea serrulata and Thalassodelldroll ciliatum. Photosynthetica 28, 307 312

II. de Boer, W.F. 2000. Biomass dynamics of seagrasses and the role of mangroves and seagrass vegetation as different nutrient sources for an intertidal ecosystem. Aquat. Bot. 66, 225-239.

12. Bandeira, S.O. and Nilsson, P.G, 2001. Genetic population structure of the seagrass Thalassodelldroll ciliotum in southern Mozambique. Mar. Bioi. 139 1007-1012.

13. Martins, A.R.O. and Bandeira, S.O. 2001. Biomass and leaf nutrients of Thalassia hemprichii at Inhaca Island, Mozambique. S. Afr. J. Bot. 67,439-442.

14. Bandeira, S.O. 2002. Leaf production rates Thalasso dendron ciliatum from rocky and sandy habitats. Aquat. Bot. 1516, 1-12.

15. Gell, F.R. and Whittington, M.W. 2002. Diversity of fishes in seagrass beds in the Quirimba Archipelago, northern Mozambique. Mar. Freshwater Res. 53, 115 121.

16. Bandeira, S.O. and Bjork, M. 2001. Seagrass research in the eastern Africa region: emphasis to diversity, ecology and ecophysiology. S. Afr. J. Bot. 67,420-425.

17. Silva, S.M.F. 1991.Cyanophyceae associated with man grove trees at inhaca Island, Mozambique Rnthn/;n 71
143-150.

18. Paula, 1., Pinto, I., Guambe, I., Monteiro, S., Gove, D.z. and Guerreiro, 1. 1998. Seasonal cycle of planktonic communities at Inhaca Island, Southern Mozambique. $J$. Plallktoll Res. 20, 2165-217

19. Isaac, W.E. 1956. Marine algae of lnhaca and of the Inhaca Peninsula I. J S. Afr. Bol. 22, 161-193.

20. Critchley, A.T., Farrell, E.G., Aken, M.E., Pienaar, R.N. 1994. A multivariate approach to the phycogeographical aspects of the seaweed flora of Inhaca Island, Mozambique. Bol. Mar. 37, 261-265.

21. Critchley, AT., Aken, M.E., Bandeira, S.O. and Kalk, M. 1997. A revised list of marine algae from Inhaca island, Mozambique. S. Afr. J. Bot. 63,426-435.

22. Bandeira, S.O. Antonio, e.M. and Critchley, AT. 2001. A taxonomic listing, including new distribution records, for benthic, intertidal seaweeds from Mecufi, northern Mozambique. S. Afr. J Bot. 67,492-496.

23. Maite-Santos, A.L and Mshigeni, K.E. 1992. Seaweeds and their uses in Mozambique. In: Proc. First Int/. Workshop on Suslaillable Seaweed Resource Developmellt in Sub-Saharan Africa, Mshigeni, K.E., Bolton, J., Critchley, A.T. and Kiangi, G.E. (eds). Windhoek, Namibia, pp. 206-212.

24. Bandeira, S.O. 1998. Seaweed resources of Mozambique. In: The Seaweed Resources of The World. Critchley, A.T. and Ohno, M. (eds). Japan International Cooperation Agency OICA), pp. 403-408

25. Schleyer, M.H. 1997. Natural history of Bazaruto Island: coral reef survey and handbook. Oeeanogr. Res. /lrst. Spec. Publ. 14O, 1-64.

26. Berggren, M. 1992. Naushollia lactoalbida, new species (Decapoda, Thalassinidea: Laomediidae), a new mud shrimp at Inhaca Island, Mozambique. J Crust. Bioi. 12,514-522.

27. Berggren, M. 1994. Periclimenes nomadophila and Tuleariocaris saree, two new species of pontoniine shrimps (Crustacea: Decapoda: Pontoniinae), from Inhaca Island, Mozambique. .J. Crust. Bioi. 14, 782. 802 .

28. Kensley, B. 198 I. On the zoogeography of Southern African decapod crustacea, with a distributional checklist of species. Smithsonian Contrib. Zool. 338, 1-64.29.

29. Brinca, L and Palha de Sousa, L 1984. Mortality rates estimates for Metapenaeus monoceros (Fabricius) of Maputo bay. Rev. Invest. Pesq. ll,41-76.

30. de Freitas, A. J. 1986. Selection of nursery areas by six southeast African Penaeidae. Estuar. Coastal SltelfSci. 23,901-908.

31. Dray, T. and Paula, $J$. 1998. Ecological aspects of the populations of the crab Dotil/aleneslrala (Hilgendorf, 1869) (Brachyura: Ocypodidae), in the tidal flats of Inhaca Island (Mozambique). J. Not. Hist. 32, 1525 1534.

32. Macia, A., Quincardete, I. and Paula, J. 2001. A comparison of alternative methods for estimating population density of the fiddler crab Uca annulipes at Saco mangrove, Inhaca Island (Mozambique). Hydrobiologia 449,213-219.

33. Gove, D. and Paula, J. 2000. Rhytmicity of larval release in three species of intertidal brachyuran crabs (Crustacea, Brachyura) from Inhaca Island (Mozambique). Mar. Bioi. /36,685-\{j91.

34. Paula, J., Dray, T. and Queiroga, H. 2001. Interaction of off.shore and inshore processes controlling settlement of braehyuran mcgalopas at Saco mangrove creek, Inhaca island (south Mozambique). Mar. Ecol. Prog. Ser. 215,251-260

35. Paula e Silva, R. 1984. Outros recursos marinhos. in "Acta do seminario conjunto Mozambique/NORAD sobre os recursos marinhos de Mozambique". Rev. Invest. Pesq. 9, 121-131. (In Portuguese).

36. de Boer, W.F., Pereira, T. and Guissamulo, A. 2000. Comparing recent and abandoned shell middens to detect the impact of human exploitation on the intcrtidal ecosystem. Aqual. Eml. 34,287-297.

37. Barnes, D.K.A. and Currie, A. 1998. Coastal shellfish resource use in the Quirimba Archipelago, Mozambique. J. Shellfish Res. 17,51-58.

38. Gove, D. and Magane, S. 1996. The status of sea turtle conservation in Mozambique. In: Status of Sea Turtle Conservation in the Western Indian Ocean. Humphrey, S.L and Salm, R.V. (eds). Regional Seas Reports and Studies. No. 165,89-94. IUCN/UNEP.

39. Howell, K. 1997. Class Reptilia. Reptiles. In: A Guide to the Seashores of Eastern Africa and the Western Indian Ocean Islands. Richmond, M.D. (ed.). Sida Department for Research Cooperation, SAREC, Stockholm, pp. for Res $366-371$

40. (]uissamulo, A.T.1993. Distribuicao e AIJlllld';licia de Mall/lferos Marinl70s nas Baias de Mapllto e Bazarl/to e Silas Interaeroes eam AlgI/mas Pescarias. Licenciatura Thesis, Universidade Eduardo Mondlane, Mozambique. 105 pp. (In Portuguese)

41. de Freitas, AJ. 1966. An analysis of the shrimp catch on the inter-tidal mudflats of Lingamo (Matola, Mozambique). Mem. IllsI. Invest. Cient. Mozambique 8 (A), 3-12.

42. Hughes, D.A. 1966. Investigations of the "nursery areas" and habitat preference of juvenile penaeid prawns in Mozambique. J. API'\%. Bioi. 3,349-354.

43. de Freitas, A.I. and Araujo, J.M. 1974. Status of the penaeid shrimp stocks of Mozambique. Coli. Sci. $\mathrm{Pa}$ pers I, 271-277. ICSEAF. Barcelona.

44. Coelho, LM. and Costa, M.L 1974. Mollusk research Mozambique. Call. Sci. Papers 1,60-62. ICSEAF. 
